\title{
PRAKTEK MANAJEMEN KINERJA DAN KINERJA ORGANISASI PADA UNIVERSITAS BATANGHARI: PERAN BUDAYA ORGANISASI SEBAGAI VARIABEL MODERATOR
}

\author{
Jonner Simarmata \\ Program Studi Manajemen FE Universitas Batanghari \\ jonnerunbari@gmail.com
}

\begin{abstract}
Many factors affect the relationship of management and performance both in the context of profit and nonprofit organization. One of the factors is culture. Researches have shown that culture may mediate or moderate the relationship. This current research investigates the moderating role of culture on the relationship of performance management and working performance of lecturers of Batanghari University. For this, a survey was conducted by distributing a questionnaire to 36 respondents randomly selected. MRA (moderated regression analysis) was used to analyze the data. The simple regression analysis (before culture added) found that performance management practices have a significant effect on lecturer performance with $67.5 \%$ of determinant coefficient. MRA analysis (after culture added), the determinant coefficient becomes $69 \%$, meaning there is an increase of $1.5 \%$. F-test shows that Sig. $=0.000$ is smaller than $\alpha=0.05$, indicating that the increase is considered significant. From this analysis, it can be concluded that culture significantly moderates performance of lecturers. Then, it is suggested that culture need to be strengthened in order to improve the relationship of performance management practices and performance of lecturers.
\end{abstract}

Key Words: performance management practices, organizational culture, lecturer performance.

\section{PENDAHULUAN}

Dosen adalah pendidik professional sekaligus ilmuan. Hal ini desebutkan dalam Undang-undang no 14 tahun 2005 tentang guru dan dosen. Tugas utamanya adalah mengembangkan dan menyebarluaskan ilmu pengetahuan, seni, dan teknologi kepada masyarakat melalui kegiatan pendidikan, penelitian dan pengabdian. Dengan demikian, kinerja dosen selalui dilihat dari tiga aspek ini. Penelitian tentang kinerja dosen telah banyak juga dilakukan. Pada umumnya, hasil penelitian menunjukkan bahwa kinerja dosen di Indonesia belum menggembirakan, terutama kinerja penelitian dan pengabdian. Faktor-faktor yang mempengaruhi kinerja dosen juga telah sering diteliti dan dikaji. Namun penelitian-penelitian tersebut lebih berfokus kepada faktor individu. Dua aspek yang paling sering dibahas adalah motivasi dan komitmen. Sedangkan faktor organisasional seperti manajemen kinerja dan budaya organisasi belum banyak dibahas. (Adisetiawan, 2013)

Penelitian tentang hubungan manajemen kinerja dengan kinerja pada konteks industri pada umumnya menunjukkan bahwa manajemen kinerja berpengaruh signifikan terhadap kinerja. Semakin efektif manajemen kinerja semakin tinggi kinerja. Namun pada konteks perguruan tinggi belum banyak bukti ditemukan. Budaya organisasi merupakan faktor penting dalam meningkatkan kinerja. Budaya organisasi yang kuat dapat meningkatkan kinerja organisasi dan kinerja individu. Bahkan disebutkan bahwa organisasi yang melakukan perubahan budaya lebih efektif dibandingkan dengan organisasi yang tidak melakukan perubahan budaya. Namun pada umumnya, budaya organisasi dilihat sebagai mediator. Bahkan, dalam konteks perguruan tinggi, budaya organisasi lebih sering diteliti sebagai mediator. Padahal, pakar berpendapat bahwa budaya organisasi dapat berperan sebagai mediator maupun sebagai moderator. Penelitian ini bertujuan untuk mengkaji peran moderasi budaya organisasi terhadap hubungan manajemen kinerja dengan kinerja pada konteks perguruan tinggi khususnya. Lebih spesifiknya, penelitian ini bertujuan untuk mengkaji dua masalah berikut: (1) bagaimana pengaruh praktek manajemen kinerja terhadap kinerja dosen?; dan (2) apakah budaya organisasi memoderasi hubungan praktek manajemen kinerja dengan kinerja dosen? 


\section{Landasan Teori}

\section{Kinerja dan Kinerja Dosen}

Amir (2016) menyimpulkan bahwa istilah kinerja memiliki beberapa atribut seperti: i) perilaku atau pekerjaan, ii) keterkaitannya dengan tujuan organisasi, iii) kandungan nilai kebermaknaan bagi organisasi, dan iv) berdimensi input, proses, output dan outcome. Berdasarkan atribut-atribut ini kemudian Amir mendefinisikan kinerja sebagai tampilan perilaku kerja yang terkait dengan misi dan tujuan organisasi, dilaksanakan sesuai dengan potensi yang dimilikinya dan ditujukan untuk menghasilkan sesuatu yang bermakna bagi organisasi dan lingkungannya. Beberapa pakar lain mendefinisikan kinerja seperti yang dikutip oleh Purwihartuti (2017) sebagai berikut. Menurut Razaei dan Baalousha, kinerja adalah efisiensi dan efektifitas organisasi yang diukur dengan mengkombinasikan faktor keuangan dan non-keuangan. Kombinasi kedua faktor tersebut berupa keuangan, operasi, jumlah, keamanan, SDM, dan kepuasan pelanggan. Menurut Daft, kinerja adalah pencapaian tujuan dan strategi organisasi. Menurut Bogoroza, kinerja adalah pencapaian hasil baik financial maupun non-financial. Berdasarkan tiga definisi ini dengan jelas terlihat bahwa ketiga pakar ini menggunakan pendekatan hasil untuk mendefinisikan kinerja.

Qomariah (2013) mengemukakan bahwa kinerja adalah gambaran mengenai tingkat pencapaian pelaksanaan suatu kegiatan dalam mewujudkan sasaran, tujuan, misi, dan visi organisasi yang tertuang dalam 'strategic planning' suatu organisasi. sedangkan pengukuran kinerja adalah suatu proses penilaian kemajuan pencapaian tujuan yang sudah ditetapkan. Proses pengukuran ini mencakup beberapa tahapan seperti (1) menetapkan tujuan, sasaran, dan strategi pencapaian tujuan tersebut, (2) merumuskan indikator dan ukuran kinerja, (3) mengukur tingkat ketercapaian tujuan dan sasaran organisasi, dan (4) melakukan evaluasi kinerja yang bertujuan untuk memberi 'feedback', menilai kemajuan organisasi, dan c) meningkatkan kualitas pengambilan keputusan dan akuntabilitas. Kinerja individu dapat dilihat dari tiga dimensi yakni kemampuan (Ability), motivasi (Motivation), kesempatan (Opportunity). Dengan kata lain P(erformance) $=($ Ability x M $\mathrm{x} O$ ). Ability adalah kemampuan yang harus dimiliki oleh dosen untuk melakukan tugas-tugas tridarma. Kemampuan tersebut terdiri dari penguasaan terhadap bidang ilmu, penguasaan metodologi penelitian, penguasaan strategi penyampaian materi kuliah, penguasaan teknik presentasi, penguasaan teknik penulisan karya ilmiah. Selain itu, dosen juga wajib memiliki apa yang diebut dengan working characters, yakni: memiliki kompetensi (competent), memiliki kemampuan bekerja sama dengan orang lain (collaborative), memiliki kemampuan menyampaikan gagasan secara jelas (communicative), kemampuan berpikir kritis (critical), kemampuan berkreasi (creative). Motivasi adalah dorongan yang dimiliki dosen untuk melakukan tugas-tugasnya dengan baik. Secara teoritis, motivasi memiliki pengaruh yang kuat terhadap kinerja. Semakin tinggi motivasi semakin tinggi pula kinerja. Terdapat banyak faktor yang mempengaruhi motivasi seseorang untuk bekerja lebih baik. Faktor kebutuhan merupakan faktor penting. Menurut Maslow manusia bekerja karena didorong oleh kebutuhan yang tersusun secara hirarkis. Artinya jika kebutuhan yang pertama telah terpenuhi kebutuhan tingkat kedua akan muncul menjadi yang utama dan seterusnya (Zahari, 2015). Beberapa faktor lain adalah kemampuan, kesempatan, dan rasa keadilan.

Opportunity adalah peluang yang dimiliki dosen untuk mengembangkan karirnya. Kesempatan atau peluang bisa juga berperan sebagai motivasi bagi dosen untuk melakuan tugasnya denganbaik. Semakin besar peluang bagi dosen untuk mengembangkan karirinya maka semakin tinggi motivasinya melakukan tugasnya. Yang menjadi pertanyaan adalah apa dan bagaimana karir dosen sebenarnya. Diyakni bahwa orang yang memiliki kemampuan yang tinggi akan memiliki kinerja yang tinggi. Demikian juga, orang yang memiliki motivasi kerja yang tinggi akan memiliki kinerja yang tinggi. Selanjutnya, bagi yang memiliki kemampuan dan motivasi kerja yang tinggi juga harus diberi kesempatan yang luas untuk mengembangkan karirnya. Singkatnya, ketiga aspek ini merupakan faktor penting dalam meningkatkan kinerja seseorang.

Dalam Undang-Undang No 14 tahun 2005 tentang Guru dan Dosen disebutkan bahwa dosen adalah pendidik professional sekaligus ilmuan. Tugas utamanya adalah mentransformasikan, mengembangkan dan menyebarluaskan ilmu pengetahuan, seni, dan teknologi kepada masyarakat melalui kegiatan pendidikan, penelitian dan pengabdian. Mengajar berkaitan kegiatan tatap muka dengan mahasiswa di dalam kelas. Sedangkan tugas meneliti berkaitan kegiatan penelitian dan publikasi hasil penelitian tersebut. Sementara itu, tugas pengabdian berkaitan dengan kegiatan penyebaran ilmu pengetahuan kepada masyarakat melalui 
kegiatan pelatihan dan sebagainya. Idealnya, materi kegiatan pengabdian didasarkan kepada hasil penelitian. Pada hakikatnya, tiga macam tugas utama dosen ini adalah saling terkait. Keterkaitannya adalah sebagai berikut: tugas mengajar harus disesuaikan dengan bidang ilmu yang dikuasai. Dengan kata lain, bidang yang diajarkan dosen adalah harus sesuai dengan kualifikasinya. Sementara itu, tugas penelitian mesti terkait dengan bidang ilmuyang dikuasai. Sedangkan tugas pengabdian harus pula sesuai dengan bidang ilmu dan idealnya didasarkan kepada hasil penelitian. Konsep tugas dosen ini sesuai dengan konsep tridarma perguruan tinggi.

\section{Manajemen Kinerja}

Perilaku (kerja) dan hasil (kerja) merupakan dua elemen penting yang mengatur kinerja. Oleh sebab itu, Daniels (1970) menyebutkan fungsi dari manajemen kinerja adalah mendeskripsikan teknologi dan mendefinisikan prosess untuk mengelola kedua elemen ini. Lebih lanjut, Daniels mengatakan bahwa elemen utama dari sistem manajemen kinerja adalah pengukuran (measurement), umpan balik (feedback), dan penguatan (reinforecement). Sementara itu, Amir (2016) mendefinisikan manajemen kinerja sebagai pemberdayaan semua sumber daya yang ada dalam organisasi secara sinerjik untuk mencapai tujuan. Sementara itu, Pride et. al (1988) mengemukakan sumberdaya organisasi terdiri dari sumberdaya manusia, sumberdaya informasi, sumberdaya material. Amir juga mengatakan bahwa manajemen kinerja adalah strategi pengelolaan unit kerja atau organisasi yang berfokus pada SDM. Mengutip Dillip Bath, Amir selanjutnya mengatakan bahwa pengembangan organisasi berasal dari $70 \%$ pengembangan SDM, $20 \%$ pengembangan proses, dan $10 \%$ pengembangan teknologi. Temuan ini menegaskan bahwa SDM memiliki peran yang sangat besar dalam meningkatkan kinerja. (Adisetiawan, 2016)

Pendapat di atas dapat disimpulkan bahwa pada hakikatnya manajemen kinerja adalah proses pengembangan SDM. Sesuai dengan konsep AMO maka pengembangan SDM dapat dilakukan dalam tiga aspek yakni pengembangan kompetensi, pengembangan motivasi, dan pengembangan kesempatan berkarir. Menurut Spencer dan Spencer (1993), kompetensi adalah beberapa karakteristik yang dapat memprediksi kinerja seseorang. Kompetensi adalah kewenangan, kecakapan, dan kemampuan untuk melaksanakan tugas atau kegiatan. Kompetensi memiliki tiga dimensi yakni perilaku, keterampilan, dan pengetahuan. Menurut Becker (2001), kompetensi adalah pengetahuan, keterampilan, dan sikap yang mempengaruhi kinerja seseorang. Semaikin tinggi kompetensi seseorang maka semakin tinggi pula kinerja orang tersebut. Menurut Undang-undang No 14 Tahun 2005 tentang Guru dan Dosen, kompetensi terdiri dari kompetensi pedagogik, kompetensi professional, kompetensi kepribadian, dan kompetensi sosial. Terdapat empat macam model kompetensi yang dapat dikembangkan, yakni: 1. Model kompetensi organisasi. Model ini bersifat generik dan merupakan deskripsi kompetensi yang diperlukan semua anggota organisasi secara umum, 2. model kompetensi fungsional, yakni standar kerja yang diperlukan setiap individu untuk melaksanakan peran dan fungsinya secara spesifik, 3. model kompetensi jabatan, yakni deskripsi kompetensi yang diperlukan untuk jabatan tertentu, dan 4. model kompetensi kepemimpinan, yakni deskripsi kompetensi yang diperlukan untuk pimpinan. Menurut konsep tridarma perguruan tinggi, dosen memiliki tugas utama yakni mengajar, meneliti, dan melakukan pengabdian kepada masyarakat (PKM). Selain itu, dosen juga memiliki tugas-tugas tambahan seperti pembimbing tugas akhir mahasiswa dan pembimbing akademik bagi mahasiswa. Untuk melaksanakan tugas-tugas ini semua, dosen perlu diberikan pelatihan yang memadai, terutama karena cepatnya perubahan ilmu dan pengetahuan sehingga pendidikan formal yang dimiliki dosen seperti yang dipersyaratkan tidak mencukupi.

Motivasi adalah dorongan atau kekuatan yang mendorong seseorang untuk melakukan sesuatu (Gibson, et al, 2003). Sedangkan menurut Karyantoro (2004), motivasi adalah kondisi yang menggerakkan seseorang seseorang untuk mencapai tujuan organisasi. Kedua definisi ini memiliki persamaan yakni bahwa motivasi dapat berasal dari diri sendiri (intrinsic) maupun dari luar (ekstrinsik). Berbagai penelitian telah mengungkapkan bahwa motivasi berpengaruh terhadap kinerja seseorang. Semakin tinggi motivasi semakin tinggi pula kinerja. Trisnaningsi (2011) mengungkapkan bahwa motivasi berpengaruh terhadap kinerja dosen. Namun yang menjadi pertanyaan adalah apakah yang menjadi faktor motivasi bagi seseorang. Maslow mengemukakan seseorang terdorong untuk melakukan sesuatu karena didorong oleh keinginan untuk 
memenuhi kebutuhannya yang tersusun secara hirarkis. Teori lain mengatakan kemampuan dan kesempatan yang dimiliki seseorang merupakan faktor penting bagi motivasi kerja.

Dalam konteks dosen terdapat beberapa faktor yang menjadi faktor motivasi bagi dosen untuk bekerja lebih baik. Beberapa faktor tersebut adalah kepemimpinan, kompensasi, sistem penilaian kinerja, dan program pengembangan. Bagi dosen, pengembangan karir merupakan aspek penting. Seperti telah disbutkan sebelumnya, karir dosen terdiri dari jabatan fungsional dan jabatan struktural. Selain itu, dosen dapat pula mengembangkan karir di luar kampus - misalnya menjadi konsultan di pemerintahan atau di korporat.

\section{Budaya Organisasi}

Budaya adalah asumsi (Schein, 1992), nilai, keyakinan, dan norma berperilaku (Kotter dan Haskett, 1998), filosofi yang menjadi karakteristik seseorang atau organisasi (Wibowo, 2016), 'collective programming of the mind' yang dapat membedakan cara berpikir, tindakan sosial, dan bahkan 'mental programs' dari anggota satu organisasi dengan organisasi lain (Ahmed and Shafiq, 2014). Robbins (1995) mengemukakan bahwa budaya berpengaruh kepada cara bersikap dan berperilaku anggota organisasi. Sementara itu, Kotter dan Haskett (1998) mengemukakan bahwa budaya merupakan faktor strategis menjelaskan kinerja. Kotter dan Haskett (1998) mengemukakan terdapat tiga macam budaya organisasi yakni (1) budaya kuat dan budaya lemah, (2) budaya cocok dan budaya tidak cocok, (3) budaya adaptif dan budaya tidak adaptif. Lebih lanjut dikatakan budaya kuat mempengaruhi kinerja secara kuat sementara budaya lemah mempengaruhi kinerja secara lemah. Nelson dan Quick (2011) mengemukakan bahwa budaya organisasi memiliki empat fungsi. Keempat fungsi tersebut adalah (1) memberi identitas keanggotaan, (2) meningkatkan komitmen, (3) memperkuat nilai organisasi, dan (4) mengatur perilaku. Perubahan lingkungan terutama lingkungan eksternal sebagai konsekwensi dari globalisasi telah membuat organisasi harus melakukan perubahan strategi bisnis agar tetap memiliki keunggulan kompetitif. Untuk itu, perubahan budaya organisasi menjadi sangat penting. Hanya dengan perubahan budaya organisasilah, kinerja organisasi dapat meningkat. Beberapa studi telah membuktikan bahwa organisasi yang melakukan perubahan budaya organisasi mampu meningkatkan kinerjanya secara signifikan dibandingkan dengan organisasi yang tidak melakukan perubahan budaya organisasi (Wibowo, 2016).

Semakin kuat budaya organisasi maka semakin kuat pula pengaruh manajemen kinerja terhadap kinerja dosen. Sebaliknya, semakin lemah budaya organisasi maka semakin lemah pula pengaruh manajemen kinerja terhadap kinerja dosen. Berdasarkan pemikiran ini maka hipotesis dapat dirumuskan sebagai berikut:

H1: Manajemen kinerja berpengaruh secara positif dan signifikan terhadap kinerja dosen. Semakin efektif manajemen kinerja semakin tinggi pula kinerja organisasi.

$\mathrm{H} 2$ : Budaya organisasi memoderasi hubungan manajemen kinerja dengan kinerja organisasi. Semakin kuat budaya organisasi maka semakin signifikan manajemen kinerja mempengaruhi kinerja organisasi.

\section{METODE}

Populasi dari penelitian ini adalah dosen tetap Universitas Batanghari yang terdiri dari 188 orang dan tersebar di lima fakultas (Simarmata, 2017). Sampel sebsnyak 36 orang atau 19\% diambil secara random. Jumlah sampel ini dianggap representatif sesuai dengan pendapat Arikunto (2016) yang mengatakan bahwa sampel dapat terdiri antara $10-20 \%$. Data dalam penelitian ini adalah data primer berupa persepsi responden terhadap indikator-indikator variable. Untuk mengumpulkan data digunakan angket yang disusun sendiri oleh penenliti. Sesuai dengan jumlah variable dalam penenlitian ini maka angket terdiri dari tiga bagian, yakni: 1) bagian praktek manajemen kinerja, 2) bagian budaya organisasi, dan 3) bagian kinerja dosen. Dalam angket, responden diminta untuk memberikan penilaian terendah sampai tertinggi dalam skala $1-5$ berdasarkan persepsi mereka terhadap indikator dari setiap variable penelitian.

\section{Teknik Analisis Data \\ Analisis Deskriptif}

Analisis deskriptif bertujuan untuk mendeskripsikan data dalam bentuk table dan menggambarkan data tersebut tanpa bermaksud melakukan generalisasi (Sugiyono, 2016). Dalam penelitian ini, data yang sudah 
dikumpulkan dimasukkan kedalam lima kategori yakni sangat tinggi, tinggi, sedang, rendah, dan sangat rendah. Untuk menentukan kategori ini digunakan standar mutlak dengan ketentuan nilai rata-rata atau mean ideal ditetapkan $60 \%$ dan standar deviasi ditetapkan $1 / 4$ dari mean ideal. Dengan demikian tingkat penilaian responden terhadap variable yang diteliti dapat ditentukan seperti terlihat pada Table 1.

Tabel 1

Kategorisasi Skor

\begin{tabular}{ccc}
\hline No & Skala & Kategori \\
\hline 1 & $83-100$ & Sangat Tinggi \\
2 & $68-82$ & Tinggi \\
3 & $53-67$ & Sedang \\
4 & $38-52$ & Rendah \\
5 & $0-37$ & Sangat Rendah \\
\hline
\end{tabular}

\section{Analisis MRA}

Analisis MRA adalah analisis yang bertujuan untuk menguji pengaruh variable moderating terhadap hubungan variable independent dengan variable dependent (Liana, 2009). Analisis MRA dilakukan dengan bantuan Program SPSS Versi 24. Hasil analisis MRA ini akan disajikan berikut ini. Dalam penelitian ini terdapat tiga maca variable yakni praktek manajemen kinerja $\left(\mathrm{X}_{1}\right)$ sebagai variable independen, budaya organisasi $\left(\mathrm{X}_{2}\right)$ sebagai variable moderating, dan kinerja dosen $(\mathrm{Y})$ sebagai variable dependent. Variabel independent adalah variable yang mempengaruhi variable dependen dan variable dependent adalah variable yang dipengaruhi variable independent. Sementara itu, variable moderating adalah variable yang memperkuat atau memeperlemah hubungan variable independent dengan variable dependent (Liana, 2009).

Praktek Manajemen Kinerja diukur dari tiga dimensi. Ketiga dimensi tersebut adalah pengembangan kompetensi $\left(\mathrm{X}_{11}\right)$ dengan lima indikator yakni: pengembangan kompetensi mengajar $\left(\mathrm{X}_{11.1}\right)$, pengembangan kompetensi meneliti $\left(\mathrm{X}_{11.2}\right)$, pengembangan kompetensi pengabdian $\left(\mathrm{X}_{11.3}\right)$, pengembnagan kompetensi bidang ilmu $\left(\mathrm{X}_{11.4}\right)$, dan pengembangan kompetensi teknologi informasi $\left(\mathrm{X}_{11.5}\right)$. Dimensi kedua adalah pengembangan motivasi $\left(\mathrm{X}_{12}\right)$ dengan lima indikator yakni: pengembangan motivasi melalui gaji, honor dan tunjangan $\left(\mathrm{X}_{12.1}\right)$, pengembangan motivasi melalui penghargaan prestasi kerja $\left(\mathrm{X}_{12.2}\right)$, pengembangan motivasi melalui peningkatan mutu sarana dan prasarana $\left(X_{12.3}\right)$, pengembangan motivasi melalui peningkatan mutu layanan administrasi $\left(\mathrm{X}_{12.4}\right)$, dan pengembangan motivasi melalui keterlibatan dosen $\left(\mathrm{X}_{12.5}\right)$. Dimensi ketiga adalah pengembangan kesempatan berkarir $\left(\mathrm{X}_{13}\right)$ dengan lima indikator yakni: kesempatan studi lanjut $\left(\mathrm{X}_{13.1}\right)$, kesempatan naik pangkat $\left(\mathrm{X}_{13.2}\right)$, kesempatan memperoleh jabatan struktural $\left(\mathrm{X}_{13.3}\right)$, kesempatan mengikuti seminar di institusi lain $\left(\mathrm{X}_{13.4}\right)$, dan kesempatan berkarir di luar institusi $\left(\mathrm{X}_{13.5}\right)$.

Budaya Organisasi diukur dari tiga dimensi yakni kolaborasi $\left(\mathrm{X}_{21}\right)$ dengan lima indikator yakni: openminded $\left(\mathrm{X}_{21.1}\right)$, mutual-trust $\left(\mathrm{X}_{21.2}\right)$, communicative $\left(\mathrm{X}_{21.3}\right)$, people-oriented $\left(\mathrm{X}_{21.4}\right)$, dan disiplin $\left(\mathrm{X}_{21.5}\right)$. Dimensi kedua adalah learning $\left(\mathrm{X}_{22}\right)$ dengan lima indikator yakni: kemauan menambah wawasan $\left(\mathrm{X}_{22.1}\right)$, kemauan mempelajari hal-hal baru $\left(\mathrm{X}_{22.2}\right)$, kemauan belajar dari masa lalu $\left(\mathrm{X}_{22.3}\right)$, kemauan belajar teknologi $\left(\mathrm{X}_{22.4}\right)$, dan kemauan mengembangkan kepribadian $\left(\mathrm{X}_{22.5}\right)$. Dimensi ketiga adalah leadership $\left(\mathrm{X}_{23}\right)$ dengan lima indikator yakni: memiliki managerial skills $\left(\mathrm{X}_{23.1}\right)$, memiliki integritas $\left(\mathrm{X}_{23.2}\right)$, memahami tupoksi $\left(\mathrm{X}_{23.3}\right)$, visioner $\left(\mathrm{X}_{23.4}\right)$, dan memiliki communication skills $\left(\mathrm{X}_{23.5}\right)$. Kinerja dosen diukur dari tiga dimensi yakni kinerja pendidikan atau pengajaran $\left(\mathrm{Y}_{1}\right)$ dengan lima indikator yakni: jumlah rata-rata tatap muka dengan mahasiswa dalam satu semester $\left(\mathrm{Y}_{11}\right)$, disiplin waktu dalam mengajar $\left(\mathrm{X}_{12}\right)$, penguasaan materi $\left(\mathrm{Y}_{13}\right)$, penguasaan metode mengajar $\left(\mathrm{Y}_{14}\right)$, keakraban dengan maahsiswa atau rapport ( $\left.\mathrm{Y}_{15}\right)$. Dimensi kedua adalah kinerja penelitian $\left(\mathrm{Y}_{2}\right)$ dengan lima indikator yakni: total publikasi hasil penelitian tiga tahun terakhir $\left(\mathrm{Y}_{21}\right)$, penguasaan metode penelitian ( $\left.\mathrm{Y}_{22}\right)$, kemampuan menulis artikel untuk jurnal ( $\left.\mathrm{Y}_{23}\right)$, kemampuan mengidentifikasi isu-isu terkini terkait bidang ilmu untuk diteliti ( $\left.\mathrm{Y}_{24}\right)$, dan kemampuan menyajikan makalah di hadapan audience $\left(\mathrm{Y}_{25}\right)$. Dimensi ketiga adalah kinerja PKM $\left(\mathrm{Y}_{3}\right)$ dengan lima indikator yakni: total kegiatan PKM tiga tahun terakhir $\left(\mathrm{Y}_{31}\right)$, kemampuan mengidentifikasi kebutuhan masyarakat $\left(\mathrm{Y}_{3.2}\right)$, penguasaan materi pengabdian $\left(\mathrm{Y}_{33}\right)$, kemampuan berbicara di hadapan publik atau public speaking $\left(\mathrm{Y}_{34}\right)$, dan kemampuan teknik presentasi $\left(\mathrm{Y}_{35}\right)$. 


\section{HASIL}

Karakteristik responden dapat dilihat pada Tabel 2. Menurut table ini, responden yang berjenis kelamin perempuan terdiri dari 54\% sedangkan sisanya $46 \%$ berjenis kelamin laki-laki. Dari segi usia diketahui bahwa $66 \%$ responden berusia antara 25 - 45 tahun sedangkan sisanya sebesar 34\% berusia 46 sampai dengan 65 tahun. Dari data ini dapat disimpulkan bahwa sebagian besar dosen Unbari masih berusia produktif. Dilihat dari masa kerja, sebagian besar responden yakni sebesar $83 \%$ dengan masa kerja antara 1 sampai dengan 20 tahun, sedangkan sisanya sebesar 17\% dengan masa kerja 21 - 30 tahun. Dengan kata lain, sebagia besar dosen Unbari masih dalam masa kerja aktif. Artinya, hanya sebagian kecil yang segera akan memasuki masa pensiun. Dari segi tingkat pendidikan teakhir diketahui bahwa responden sebagian besarnya yakni sebesar $86 \%$ memiliki kualifikasi S-2 dan hanya 14\% yang memiliki kualifikasi S-3, dan yang memiliki kualifikasi S1 tidak ada lagi. Dengan demikian dapat disimpulkan bahwa dosen-dosen Unbari telah memenuhi syarat minimal dalam hal kualifikasi yakni minimal S-2. Namun demikian, idealnya dosen harus memiliki kualifikasi S-3. Hal ini sejalan dengan hasil beberapa penelitian yang mengatakan bahwa mahasiswa cenderung menginginkan dosen dengan kualifikasi S-3.

Tabel 2

Karakteristik Responden

\begin{tabular}{ccccc}
\hline No & Kategori & Sub-kategori & Frekwensi & $\%$ \\
\hline \multirow{2}{*}{1} & Jenis kelamin & Laki-laki & 16 & 46 \\
& & Perempuan & 20 & 54 \\
2 & Usia & $25-45$ tahun & 24 & 66 \\
& & $46-65$ tahun & 12 & 34 \\
3 & Masa Kerja & $1-10$ tahun & 21 & 58 \\
& & $11-20$ tahun & 9 & 25 \\
& & $21-30$ tahun & 6 & 17 \\
4 & Tingkat Pendidikan & S3 & 5 & 14 \\
& Terakhir & S2 & 31 & - \\
& & S1 & - & - \\
& & Guru Besar & - & 11 \\
5 & Jabatan Fungsional & Lektor kepala & 4 & 36 \\
& & Lektor & 13 & 31 \\
& & Asisten Ahli & 11 & 22 \\
\hline
\end{tabular}

Sumber: Diolah dari data primer

Segi karir nampaknya dosen-dosen Unbari belum berkembang karirnya. Hal ini terlihat bahwa sebagian besar responden yakni sebesar $67 \%$ baru memiliki kepangkatan fungsional yakni lektor $36 \%$ dan asisten ahli $31 \%$. Bahkan masih terdapat dosen yang belum memiliki kepangkatan fungsional yakni sebesar $22 \%$. Hanya sebagian kecil yakni sebesar $11 \%$ responden yang memiliki kepangkatan lektor kepala. Sedangkan yang memiliki kepangkatan guru besar belum ada. Data ini menunjukkan bahwa program pengembangan karir di Unbari belum begitu memuaskan.

\section{Deskripsi Data Variabel}

Hasil tabulasi data terhadap seluruh indikator yang membentuk variable penelitian dapat dilhat pada Tabel 3.

Tabel 3

Tabulasi Skor Variabel Penelitian

\begin{tabular}{llrrrrr}
\hline \multicolumn{1}{c}{ Variabel } & \multicolumn{1}{c}{ Sub-variabel } & Skor Max & Skor Diperoleh & $\%$ & Kategori \\
\hline Praktek & Pengembangan kompetensi & 900 & 637 & 71 & Tinggi \\
Manajemen & Pengembangan Motivasi & 900 & 561 & 62 & Sedang \\
Kinerja & Pengembangan Kesempatan berkarir & & 900 & 648 & 72 & Tinggi \\
& & Total & $\mathbf{2 7 0 0}$ & $\mathbf{1 8 4 6}$ & $\mathbf{6 8}$ & Tinggi
\end{tabular}

Praktek Manajemen Kinerja dan Kinerja Organisasi pada Universitas Batanghari: Peran Budaya Organisasi Sebagai Variabel Moderator 


\begin{tabular}{|c|c|c|c|c|c|c|}
\hline \multirow{4}{*}{ Budaya Organisasi } & Kolaborasi & & 900 & 633 & 70 & Tinggi \\
\hline & Learning & & 900 & 593 & 66 & Sedang \\
\hline & Leadership & & 900 & 614 & 68 & Tinggi \\
\hline & & Total & 2700 & 1840 & 68 & Tinggi \\
\hline \multirow{4}{*}{ Kinerja Dosen } & Kinerja pengajaran & & 900 & 672 & 75 & Tinggi \\
\hline & Kinerja penelitian & & 900 & 545 & 61 & Sedang \\
\hline & Kinerja PKM & & 900 & 532 & 59 & Sedang \\
\hline & & Total & 2700 & 1749 & 65 & Tinggi \\
\hline
\end{tabular}

Sumber: pengolahan data primer

Secara umum dapat dikatakan bahwa praktek manajemen kinerja dengan skor 68 dan budaya organisasi dengan skor 68 termasuk ke dalam kategori tinggi. Namun, kinerja dosen dengan skor 65 masuk ke dalam kategori sedang. Bila dianalisis lebih lanjut dapat diketahui bahwa pengembangan kompetensi dan karir dosen berada pada kategori tinggi. Akan tetapi, pengembangan motivasi dinilai dalam kategori sedang. Dari segi budaya organisasi terlihat bahwa kolaborasi dan leadership berada pada kategori tinggi. Namun, budaya learning berada pada kategori sedang. Kinerja dosen secara umum dinilai tinggi. Namun secara spesifik, kinerja penelitian dan kinerja PKM dinilai sedang. Dan kinerja pengajaran dinilai tinggi.

\section{Uji Hipotesis}

Hipotesis yang diajukan dalam penelitian ini adalah bahwa budaya organisasi dapat memoderasi hubungan praktek manajemen kinerja dengan kinerja dosen. Dengan kata lain, budaya organisasi dapat mempengaruhi kuat-lemahnya pengaruh praktek manajemen kinerja terhadap kinerja dosen. Untuk membuktikan hipotesis ini telah dilakukan analisis MRA (moderated regression analyisis) dengan bantuan Program SPSS versi 24. Analisis MRA terdiri dari 2 tahap. Tahap pertm yakni melakukan analisis regressi sederhana dimana variable moderasi belum dimasukkan. Pada tahp kedua adalah lanjutan dari analisis regresi sederhana dengan memasukkan variable moderasi dalam hal ini budaya organisasi. Hasil MRA dimaksu dapat dilihat pada table-tabel Summary dan ANOVA berikut:

Tabel 4

Model Summary (1)

\begin{tabular}{llrrr}
\hline Model & $\mathrm{R}$ & R Square & Adjusted R Square & Std.Error of the Estimate \\
\hline 1 & $.821^{\mathrm{a}}$ & .675 & .665 & 3.94349 \\
\hline
\end{tabular}

Sumber: data olahan

Tabel 5

ANOVA (1)

\begin{tabular}{llrrrrr}
\hline Model & & Sum of squares & df & Mean square & F & Sig. \\
\hline 1 & Regression & 1095.818 & 1 & 1095.818 & 70.466 & $.000^{\mathrm{b}}$ \\
& Residual & 528.738 & 34 & 15.551 & & \\
& Total & 1624.556 & 35 & & & \\
\hline
\end{tabular}

Sumber: data olahan

Tabel 4 dan Tabel 5 atas terlihat bahwa nilai R Square adalah 0.675. Ini menunjukkan bahwa variable Praktek Manajemen Kinerja dapat memprediksi nilai kinerja dosen sebesar 67.5\%. Sedangkan sisanya sebesar 32.5 diprediksi oleh variable lain yang tidak diteliti. Uji F memperlihatkan bahwa nilai signifikansi (Sig.) adalah 0.000 lebih kecil dari $\alpha=0.05$. Sehingga dapat disimpulkan bahwa Ho ditolak dan Ha diterima. Ini berarti pengaruh praktek Manajemen Kinerja X1) terhadap kinerja dosen adalah signifikan.

\section{Tabel 6}

Model Summary (2)

\begin{tabular}{|c|c|c|c|c|}
\hline Model & $\mathrm{R}$ & R Square & Adjusted R Square & Std.Error of the Estimate \\
\hline 1 & $.830^{\mathrm{a}}$ & .690 & .660 & 3.97002 \\
\hline
\end{tabular}

Sumber: data olahan 
Tabel 7

ANOVA (2)

\begin{tabular}{llrrrr}
\hline Model & & Sum Squares & df & Mean Square & F \\
\hline 1 & Regression & 1120.202 & 3 & 373.401 & 23.691 \\
& Reidual & 504.353 & 32 & 15.761 & $.000^{\mathrm{b}}$ \\
& Total & 1624.556 & 35 & & \\
\hline
\end{tabular}

Sumber: data olahan

Tabel 6 dan Tabel 7 terlihat bahwa R square adalah 0.690. Ini berarti praktek manajemen kinerja dapat memprediksi kinerja dosen sebesar 69\%. Ini juga berarti adanya peningkatan pengaruh praktek manajemen kinerja terhadap kinerja dosen dari $67.5 \%$ menjadi $69 \%$ setelah variable budaya organisasi ditambahkan, yang artinya juga terjadi peningkatan pengaruh sebesar 1.5\%. Tabel ANOVA juga menunjukkan bahwa nilai signifikansi adalah 0.000 lebih kecil daripada alfa sebesar 0.05. Ini juga berarti pengaruh praktek manajemen kinerja terhadap kinerja dosen adalah signifikan. Dengan demikian dapat disimpulkan bahwa budaya organisasi $\left(\mathrm{X}_{2}\right)$ dapat berperan sebagai moderator terhadap hubungan praktek manajemen kinerja dengan kinerja dosen.

\section{SIMPULAN}

Berdasarkan penilaian responden 1) praktek manajemen kinerja cukup efektif, budaya organisasi cukup kuat, dan kinerja dosen dalam kategori sedang, 2) praktek manajemen kinerja berpengaruh langsung secara signifikan terhadap kinerja dosen, dan 3) budaya organisasi dapat memoderasi hubungan praktek manajemen kinerja dengan kinerja dosen.

\section{DAFTAR PUSTAKA}

Adisetiawan, R., 2013, Kajian Persepsi Pemilik Usaha Kecil dan Menengah (UKM) Terhadap Laporan Keuangan, Jurnal Ilmiah Universitas Batanghari, 13(4), 162-173

Adisetiawan, R, 2016, Faktor yang Mempengaruhi Lulusan SMA dalam Memilih Fakultas Ekonomi Program Studi Manajemen Universitas Batanghari, Jurnal Ilmiah Universitas Batanghari, 13(4), 162-173

Ahmed, Mashal dan Shafiq, Shaima, 2014, The Impact of Organizational Culture on Organizational Performance: A Case Study of telecom Sector, Global Journal of Management and Business Research (A) Volume XIV Issue III Version I, pp 21-29.

Amir, Mohammad Faisal, 2016, Manajemen Kinerja Perguruan Tinggi, Penerbit Mitra Wacana Media, Jakarta.

Arikunto, Suharsimi, 1996, Prosedur Penelitian: Suatu Pendekatan Praktek, Jakarta: PT Rineka Cipta.

Beesly, Lisa, 2008, Defining Knowledge Management (KM) Activities: Towards Concencus, Journal of Knowledge Management, Vol 12 (3) pp 48-62.

Biantoro, Udan, 2002, Pengaruh Praktek Manajemen Sumber Daya Manusia terhadap Budaya Organisasi dan

Kinerja Perusahaan, Disertasi, Program Pascasarjana Universitas Airlangga.

Budihardjo, Andreas, 2017, Knowledge Management, Jakarta: Preasetya Mulya Publishing.

Daniels, Aubrey C., 2014, Performance Management: Changing Behaviors that Drives Organizational Effectiveness, Performance Improvement Volume 53 (10).

Dessler, Garry, 2003, Manajemen Sumber Daya Manusia, Edisi Kesepuluh Jilid 1, Penterjemah: Paramita Rahayu, Jakarta: Penerbit Indeks.

Haryono, Siswoyo, 2017, Metode SEM untuk Penelitian Manajemen, Jakarta: Penerbit Luxima Metro Media.

Imran, Muhammad Kashif, Ilyas, Muhammad, and Fatima, Tehreem (2017), Achieving Organizational Performance through Knowledge Management Capabilities: Mediating Role of Organizational Learing, Pakistan Journal of Commerece and Social Science, Vol 11 (1), 105-124.

Indrajit, Richardus Eko dan Djoko Pranoto, Richardus, 2006, Manajemen Pendidikan Tinggi Modern, Yogyakarta: CV Andi Offset. 
Liana, Lie, 2009, Pengaruh MRA dengan SPSS untuk Menguji Pengaruh Variabel Moderating terhadap Hubungan antara Variabel Independent dengan Variabel Dependent, Jurnal Teknologi Informasi DINAMIK Volume XIV (2), 90 - 97.

Mahmudi, 2015, Manajemen Kinerja Sektor Publik, Edisi Ketiga, Yogyakarta: Unit Penerbit dan Percetakan Sekolah tinggi Ilmu Manajemen YKPN.

Northouse, Peter G., 2016, Kepemimpinan: Teori dan Praktek, Edisi Keenam, Ati Cahayani: Penerjemah, Jakarta: Penerbit Indeks.

Purwihartuti, Koernia, 2017, Kinerja Program Studi sebagai Hasil dari Sistem Manajemen Mutu, Pembelajaran Organisasional, Proses Manajemen Pengetahuan, dan Modal Intelektual: Survey terhadap Program Studi pada Politeknik di Jawa Barat, Ringkasan Disertasi, Universitas Padjadjaran Bandung.

Qomariah, Nurul, 2013, Kinerja Manajemen Perguruan Tinggi Ditinjau dari Perspektif Pelanggan dan Perspektif Pembelajaran dan Pertumbuhan (Studi Kasus pada Universitas Muhammadyah Jember, Jurnal Akuntasi dan Investasi Vo.14 No. 1 halaman 32-49.

Robbins, Stephen P., dan Coulter, Mary, 2002, Manajemen, Edisi Ketujuh Jilid 1, Alih Bahasa: T. Hermaya dan Harry Slamet, Jakarta: PT Indeks.

Sartika, Yuda dan Wijaya, Chandra, 2014, Pengukuran Kinerja Perguruan Tinggi Badan Hukum Milik Negara (PTBHMN) dengan Pendekatan Balanced Scorecard, FISIP UI.

Simarmata, Jonner, 2017 Korelasi Persepsi Dosen terhadap Kemampuan Managerial Dekan dengan Motivasi Berprestasi Dosen di Lingkungan Universitas Batanghari, Ekonomis: Journal of Economics and Business Volume 1 (1) pp89-101.

Spencer, Lyle and Signa M. Spencer, 1993, Competence at Work, Models for superior Performance, Canada: John Wiley \& Sons, Inc.

Sugiyono, 2016, Metode Penelitian Manajemen, Bandung: Penerbit Alfabeta.

Undang-undang Republik Indonesia No 14 Tahun 2005 tentang Guru dan Dosen

Wibowo, 2016, Budaya Organisasi: Sebuah Kebutuhan untuk Meningkatkan Kinerja Jangka Panjang, Edisi Kedua, PT RajaGrafindo Persada, Jakarta.

Xiaomin, Cui dan Junchen, Hu, 2012, A Literature Review on Organization Culture and Corporate Performance, International Journal of Business Administration, Volume 3(2) 28-37.

Zahari, M., 2015, Pengaruh Motivasi Terhadap Disiplin Kerja Pegawai pada Dinas Perindustrian dan Perdagangan Provinsi Jambi. Jurnal Ilmiah EKSIS, Vol.6 No.1, Mei 2015. 